\title{
Managed Care and Community Health Centers
}

\author{
Leiyu Shi, DrPH, MBA \\ Kevin D. Frick, PhD \\ Bonnie Lefkowitz, MPA \\ Julia Tillman, MPA
}

\begin{abstract}
This study has two objectives: (1) to examine the relationship between the involvement of community health centers (CHCs) in managed care and various center characteristics, including patient, provider, services, and financial characteristics, that are critically linked with the fulfillment of their mission and (2) to identify factors significantly associated with CHCs' involvement in managed care. Regarding the first objective, the study indicates that CHCs involved in managed care have more diversified sources of revenue and depend less on grant funding than other CHCs, and they serve a significantly smaller proportion of uninsured and homeless patients. Involvement in managed care is also associated with greater financial vulnerability, reflected in higher costs and net revenue deficits. Regarding the second objective, the study finds that $\mathrm{CHCs}$ have become involved in managed care largely in response to external market pressures, such as the prospect of reduced federal grant funding. Other significant factors include center size, location, and the percentage of users who are Medicaid patients. Key words: community health center, managed care, Medicaid Uniform Data System
\end{abstract}

$\mathbf{I}^{\mathrm{r}}$ N RECENT YEARS, many states have turned to managed care as a way to address rising costs and access problems for their Medicaid population (Alpha Center, 1995; Oliver, 1998). Under prepaid managed care, health care organizations are paid a per capita amount each month to provide for contracted medical services (U.S. General Accounting Office [GAO], 1995). In 1996, over 13 million Medicaid recipients $(40.1 \%)$ nationwide were enrolled in managed care (prepaid as well as primary care case management), representing a more than threefold increase in enrollment levels over 1991 (9.5\%) (Health Care Financing Administration, 1996). The rapid transformation of Medicaid has affected safety-net providers, including community health centers, which provide services to nearly $8 \%$ of the nation's Medicaid population.

Since their inception in the 1960s, community health centers ( $\mathrm{CHCs}$ ) have provided a primary care safety net for the nation's poor and underserved in both inner-city and rural areas (U.S. Senate, 1988). CHCs incorporate the concepts of comprehensive and coordinated health services along with continuity of care within a single institutional setting by providing integrated care,

Leiyu Shi, DrPH, MBA, Associate Professor, Department of Health Policy and Management, Johns Hopkins School of Public Health and Hygiene, Baltimore, Maryland; Associate Director, Primary Care Policy Center for the Underserved, Baltimore, Maryland

Kevin D. Frick, PhD, Assistant Professor, Department of Health Policy and Management, Johns Hopkins School of Public Health and Hygiene, Baltimore, Maryland

Bonnie Lefkowitz, MPA, Consultant/Writer, Bethesda, Maryland

Julia Tillman, MPA, Health Policy Analyst, Bureau of Primary Health Care, Health Resources and Services Administration, U.S. Department of Health and Human Services, Bethesda, Maryland

The authors would like to acknowledge the support from the Bureau of Primary Health Care, Health Resources and Services Administration. At the time of writing Bonnie Lefkowitz was Associate Bureau Director for Data, Evaluation, Analysis, and Research, Bureau of Primary Health Care, Health Resources and Services Administration, U.S. Department of Health and Human Services.

J Ambulatory Care Manage 2000, 23(1), 1-22

(C) 2000 Aspen Publishers, Inc. 
including primary and preventive care services. Their central mission is to increase access to community-based primary health care services and improve the health status of medically underserved populations.

Called by various names-neighborhood health centers, community health centers, family health centers, migrant health centers, and rural health initiatives-CHCs, whose ranks numbered 685 organizations in 1996, served an estimated 8 million people during that year, including 5.2 million whose income was below the poverty line and another 1.6 million whose income was between the poverty line and 200\% above the poverty line. Data collected through the Bureau of Primary Health Care shows that their patients are primarily drawn from specific ethnic or racial minority groups: $28 \%$ black, $32 \%$ Hispanic, and $4 \%$ other minority groups.

CHCs employ a sliding fee schedule based on patient income and seek direct and third-party reimbursement for services. Nationally, about $28 \%$ of CHCs' revenues are derived directly from the federal government through funds authorized under Section 330 of the Public Health Service Act plus other federal grants. Remaining funds come from Medicare (7\%); Medicaid (34\%); other third parties $(8 \%)$; state, local, and private grants $(17 \%)$; and direct patient fees $(6 \%)$. The federal and other grant funds are used largely to support care for the uninsured, who constitute $40 \%$ (3.2 million) of health center patients. The 1989 federally qualified health center (FQHC) legislation, which required states to pay $\mathrm{CHCs}$ for Medicaid services on the basis of reasonable cost, significantly increased the amount and proportion of $\mathrm{CHC}$ revenues attributable to Medicaid and facilitated expansion of capacity (LewisIdema, Chu, Hughes, \& Lefkowitz, 1998). As a result, both Medicaid recipients receiving care from $\mathrm{CHCs}$ and total $\mathrm{CHC}$ service users, including the uninsured, increased as grant funds previously subsidizing Medicaid were freed up.

The rapid increase of managed care participation among CHCs is no accident. Concerned that they may lose Medicaid patients, who account for one-third of their funding, an increasing number of CHCs are participating in Medicaid managed care arrangements. Since the onset of Medicaid managed care, four major models of $\mathrm{CHC}$ participation have emerged:

1. CHCs contract directly with the state within the context of primary care case management (PCCM). Centers receive cost-based reimbursement as well as a case management fee.

2. CHCs subcontract with health maintenance organizations (HMOs) as a primary care provider, usually bearing some risk associated with primary care delivery.

3. CHCs form networks with other providers for the purpose of group contracting with an HMO.

4. CHCs form their own managed care plans and contract directly with the state for full risk (Bonnie Lefkowitz BPHC, personal communication, 1998).

In 1991, there were $41 \mathrm{CHCs}$ with managed care arrangements $(6 \%$ of the total number of CHCs). By 1996, 308 CHCs (45\% of the total number) had managed care arrangements, more than a sixfold increase (see Figure 1). Total managed care enrollment, including Medicaid, Medicare, and commercial payer-insured patients, was over 1.2 million.

While CHCs are seeking to maintain or expand the number of their Medicaid patients insured by managed care organizations (MCOs), the centers may be attractive to MCOs because they are located in target communities, offer support services to Medicaid recipients, and have established relationships with these patients (Abrams et al., 1995). CHCs are also recognized by MCOs and Medicaid agencies as cost-effective providers of care for the high-risk, vulnerable Medicaid population (Abrams et al., 1995; Lewin-VHI and MDS Associates, 1994).

Although managed care may help CHCs sustain their revenue sources, it has created a series of concerns. First, as Medicaid reimbursements decrease, centers are having trouble maintaining their service capacity. This is happening 


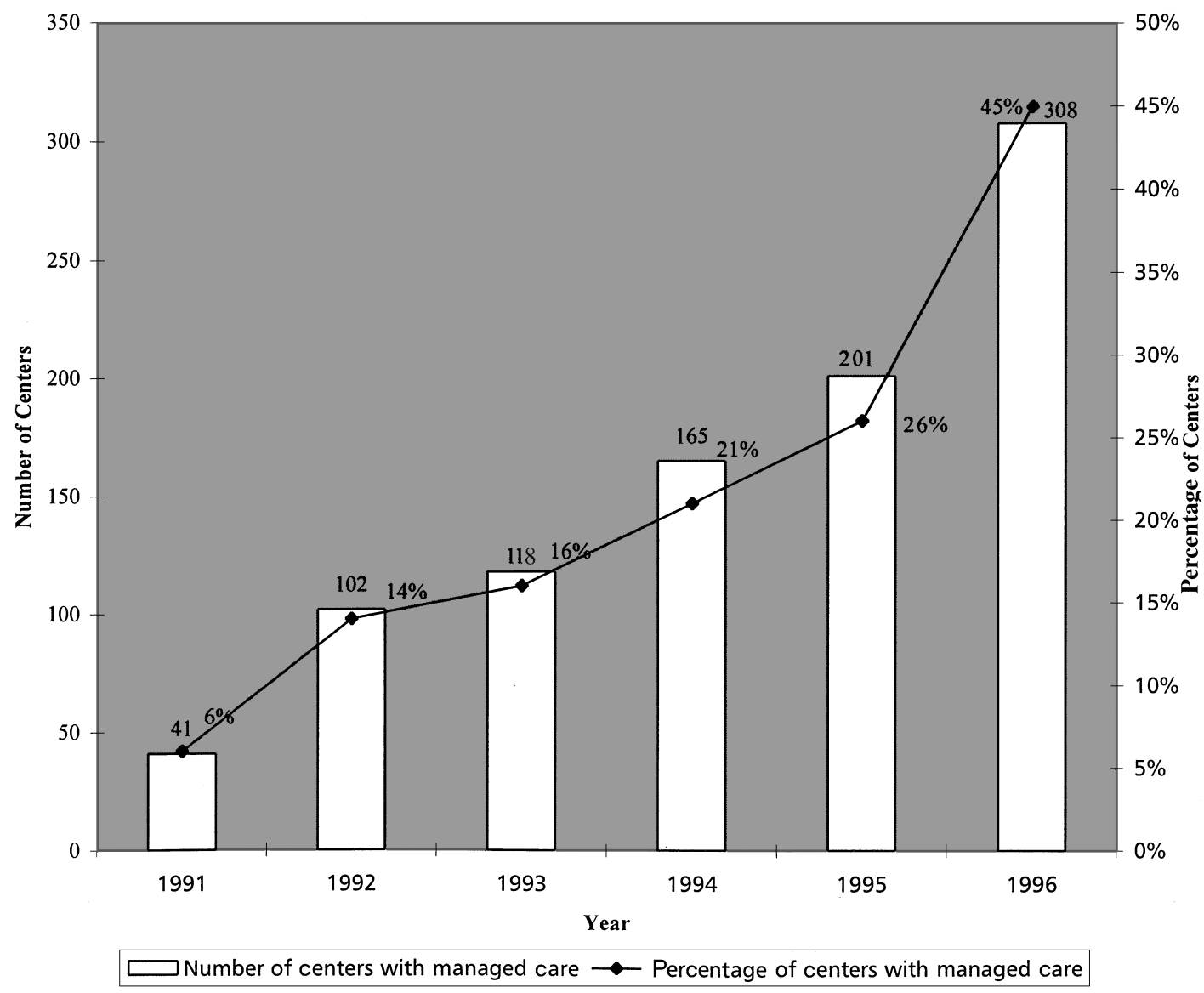

Figure 1. Community health centers and managed care.

at the same time that they are seeing growing numbers of uninsured people. Moreover, declining employment-based coverage contributes to the increase in the uninsured, thus exacerbating the demand for uncompensated care (Employee Benefits Research Institute, 1995). Henderson and Markus (1996) note that the ability of CHCs to provide community-based primary care to all medically underserved populations might be in jeopardy because of a reduction in Medicaid reimbursement and the increase in the uninsured.

Second, restricted revenues may affect the CHCs' ability to continue to provide nonreimbursable services under managed care, such as enabling services and culturally sensitive services, including translation, nutrition, counseling, and outreach (GAO, 1995; Abrams et al., 1995).

Third, prepaid managed care also exposes $\mathrm{CHCs}$ to significant financial risk. They may be especially vulnerable financially if they have capitation rates that do not fully cover their cost of services, have assumed financial responsibility for services other than primary care, and get a sizable portion of total revenues from Medicaid prepaid managed care (GAO, 1995).

Fourth, CHCs dealing with managed care for the first time are likely to face additional requirements that demand improved internal accounting and integrated management information systems. 
New staff might have to be hired to deal with managed care plans and monitor costs. All these changes necessitate significant financial outlays, which could increase costs of services and threaten financial sustainability.

Fifth, centers may lose Medicaid managed care patients through head-to-head competition with other providers or disadvantageous enrollment practices.

The purpose of this study was to examine the relationship between $\mathrm{CHCs}$ ' involvement in managed care and various center characteristics critically linked with the fulfillment of the CHCs' mission. Specifically, we compared centers with different levels of managed care involvement in terms of a host of patient, provider, services, and financial characteristics. The purpose of the comparisons was to provide evidence to determine whether and to what extent the concerns listed above have become reality. Further, the study identified factors significantly associated with CHCs' involvement in managed care. Knowledge of these factors would help in the development of a theory of managed care contracting for $\mathrm{CHCs}$ and assist policy makers in anticipating future managed care contracting within CHCs.

\section{METHODS}

\section{Data}

The data for this study primarily came from the 1996 Uniform Data System (UDS) maintained by the Bureau of Primary Health Care (BPHC), a component of the Health Resources and Services Administration of the Department of Health and Human Services. Started in 1996, UDS is an integrated reporting system that provides uniformly defined data for major BPHC grant programs and yields consistent information on center, patient, and clinical characteristics that can be compared with other national and state data (Bureau of Primary Health Care [BPHC], 1995). The 1996 UDS contains data on 685 BPHC-funded CHCs, which form the universe of our study population.

In addition to UDS, we also obtained data from the Health Care Financing Administration
(HCFA) on the status of states' implementation of the Comprehensive Health Care Reform Demonstrations or Medicaid statewide Section 1115 research and demonstration waiver. To the extent that CHCs view Section 1115 waivers as requiring their involvement in managed care to maintain market share, the increase in CHCs' involvement in managed care may be attributed to the implementation of Section 1115 waiver programs by the states (Henderson \& Markus, 1996).

\section{Measures \\ Managed care}

For the purpose of this study and based on the UDS manual, managed care was defined as any prepaid arrangement health centers have made with a third party, including Medicaid, Medicare, and private HMOs and PPOs. CHCs' involvement in managed care is obtained from UDS Table 9C. All grantees participating in Medicare, Medicaid, private, or other managed care plans are required to complete this table. The data collected include information on revenue received and expenses for prepaid plans and information on the number of enrollees in different managed care plans. Using information from this table and information on center revenue and users, we define CHCs' involvement in managed care in terms of two indicators: managed care revenues and managed care enrollees. These two indicators were also used in the site selection for a case study of managed care CHCs (Abrams et al., 1995). Many studies have used enrollees as a measure to capture managed care experience at the national (Ermann \& Richmond, 1994; Hoy, Curtis, \& Rice, 1991; Iglehart, 1992; Zarabozo, 1996), regional (Gold, 1991), state (Gold, 1991), local (Feldman, Kralewksi, \& Qowd, 1989; Gold, 1991), and organizational (Gold, 1991; Iglehart, 1994) levels. Research also has used revenue to measure product line within a plan or organization (Hoy et al., 1991). The sources of managed care revenues and enrollees are Medicaid, Medicare, private HMOs or PPOs, and other. 
For the purpose of this study, CHCs' involvement in managed care was defined as a continuum, including:

- high-volume and high-revenue managed care CHCs (HVHR centers); that is, CHCs whose prepaid enrollees constituted at least $10 \%$ of total users (note that not all enrollees are users for a given year) and whose revenue from prepaid managed primary care was at least $5 \%$ of total revenue

- high-volume and low-revenue managed care CHCs (HVLR centers); that is, CHCs whose managed care enrollees constituted at least $10 \%$ of the users but whose revenue from prepaid managed primary care was more than $0 \%$ and less than $5 \%$ of total revenue

- low-volume and low-revenue managed care CHCs (LVLR centers); that is, CHCs whose managed care enrollees constituted more than $0 \%$ and less than $10 \%$ of total users and whose revenue from prepaid managed primary care was more than $0 \%$ and less than $5 \%$ of total revenue

- non-managed-care CHCs; that is, $\mathrm{CHCs}$ with no managed care enrollees and no revenue from prepaid managed primary care

Centers with fewer than 10 managed care enrollees and less than $\$ 100$ in managed care revenue were considered outliers and were grouped in the non-managed-care category as well.

The choice of $10 \%$ cutoff for enrollees and $5 \%$ for revenue was based on the distribution of these two measures among CHCs. Sensitivity analysis performed using slightly different cutoff points yielded similar results. Further, we performed an analysis with a less restrictive definition of managed care revenue: total (rather than just primary care) prepaid managed care revenue. Total prepaid managed care revenue includes specialty and inpatient referral expenses and is not reported as part of the centers' scope of services in other revenue tables. Since the two methods produced almost identical results, we present only those based on the more restrictive definition of managed care revenue.

We divided centers into these categories so that not only could we compare centers involved in managed care with those that were not but we could compare centers with different levels of involvement. Policy makers are likely to be particularly interested in the comparison between HVHR centers and HVLR centers to assess the potential impact of low managed care revenue on financial and clinical performance.

\section{Center characteristics}

The center characteristics examined included those related to patients, providers, services, and financial performance. Most of the measures were directly available from the UDS. The financial measures of stability, efficiency, and productivity were created based on industry standards, prior research, and our experience (Feldman, Dietz, \& Brooks, 1978; Mullner, 1990; Mullner, Rydman, Whiteis, \& Rich, 1989; Rosenblatt \& Moscovice, 1982; Shi et al., 1994; Walleck \& Kretz, 1981).

The variables representing "self-sufficiency," grant revenue, service revenue, and net revenue were used to measure financial stability. Selfsufficiency, expressed as a percentage, was interpreted as an estimate of a program's subsidy gap - the difference between what a program can pay for its health care, whether through insurance (including both public and private) or patients themselves, and what it costs for the program to provide acceptable health care (Health Services Research Center, 1983). Programs with self-sufficiency ratios less than 1 required federal and other grants to cover their costs, generally because they served a large proportion of uninsured patients. This measure was based on a similar ratio developed by Feldman, Dietz, and Brooks (1978) and modified by others studying primary care projects (Rosenblatt \& Moscovice, 1978; Rosenblatt \& Moscovice, 1982; Wallack \& Kretz, 1981). Grant revenue was the percentage of total revenue that came from public sources (e.g., federal, state, or local) and private 
sources (e.g., the Robert Wood Johnson and Kellogg Foundations) as subsidies for services. Service revenue was the percentage of total revenue that came from direct payments for services, either by patients themselves or through thirdparty payers. Net revenue was used to reflect the program's financial status (Hadley, Mullner, \& Feder, 1982; Kilstein, Sanders, \& Schieber, 1980).

Efficiency was measured by average program costs, defined as the total program costs divided by the total number of medical encounters or visits (Health Services Research Center, 1983). Average cost per encounter has been used as a measure of efficiency related to ambulatory care as well as other health care settings (Frech \& Ginsburg, 1974; Golladay, Manser, \& Smith, 1974; Rosenblatt \& Moscovice, 1978). Average personnel costs were also included to measure the average costs of employing medical and support staff, including physicians, midlevel practitioners (MLPs), nurses, administrators, and others. Average medical costs were the average costs of physicians, and average administrative costs were the average costs of administrators.

Provider productivity was measured by the number of encounters or visits per MD or MLP (midlevel practitioner). CHCs are staffed by primary care physicians (e.g., general and family practitioners, internists, and pediatricians) and MLPs (e.g., physician assistants [PAs], nurse practitioners [NPs], and certified nurse midwives) (Samuels \& Shi, 1992). CHCs requesting federal funds authorized by community or migrant health center programs were formerly required to maintain a minimum number of patient encounters per provider as a condition of approval for funding (Health Services Research Center, 1983). Since the measure does not account for patient case-mix or outcome, productivity is currently one of several variables considered in funding adjustment but is not used as an explicit requirement. Appendix A provides definitions and descriptive statistics for the variables used in the analyses.

\section{Correlates of CHCs' involvement in managed care}

Organizations are now viewed, not as closed systems operating autonomously within fixed boundaries, but as open systems operating in close association with the external environment (Hannan \& Freeman, 1977; Scott 1987). The open system perspective emphasizes the importance of environment and demonstrates how it exerts its influence. Organizations are seen to be transacting with other elements of their environment to acquire needed resources and thus are often subject to some form of external control. Consequently, to understand organizational actions, it is necessary to take into account an organization's external environment and the extent to which the organization depends on it for critical resources.

Guided by the open system perspective and by research on the determinants of health services organizations' strategic orientation (Ginn \& Young 1992), we conceptualize CHCs' involvement in managed care as influenced by both external environmental and internal organizational characteristics. As regards external determinants, following Porter (1980), we treat market structure and general economic conditions as factors that influence an organization's choice of strategy. The involvement by states in managed care for their Medicaid population also provides an impetus for CHCs to get involved in managed care. CHCs, founded in the 1960s as anti-mainstream providers of health care, have been interacting with their environment for some time to maximize revenue streams; they must now interact even more comprehensively lest they lose Medicaid patients.

Under current law, a state must obtain a waiver from the U.S. Department of Health and Human Services if it wants to require Medicaid beneficiaries to enroll in a managed care program. Absent a waiver, enrollment must be the voluntary choice of the beneficiary. Although both the freedom-of-choice waiver (1915b) and the 
research and demonstration waiver (1115) may be used by states, we choose to use a state's Section 1115 waiver status as a measure of external market forces, because demonstration waiver authority permits states to try out a far greater range of policies than would otherwise be permissible in ordinary freedom-of-choice waiver programs. Specifically, CHCs situated in states that received approval for and implemented Section 1115 waiver programs during or before 1996 (when UDS data were collected) were expected to be more likely to get involved in managed care than CHCs in states that did not implement the Section 1115 waiver. The states that implemented the Section 1115 waiver during or before 1996 are Arizona, Delaware, Hawaii, Minnesota, Ohio, Oklahoma, Oregon, Rhode Island, Tennessee, and Vermont.

With respect to economic factors, external funding sources (e.g., grant funding) and payer mix could influence choice of strategy (Ginn \& Young, 1992). Thus, CHCs receiving less funding from grants may have to reduce their services to the uninsured. CHCs with relatively large Medicaid revenues are expected to be more motivated to get involved in Medicaid managed care to retain and expand their patient base. However, it is also possible that CHCs with few Medicaid patients may get involved in Medicaid managed care to attract more Medicaid enrollees. In addition, population density, as measured by rural versus urban location, is expected to have an important impact on the feasibility of managed care (Kronick, Goodman, Wennberg, and Wagner, 1993). Managed care has achieved insignificant penetration in rural areas not only because these areas have relatively sparse populations (Kronick et al., 1993; Wellever \& Deneen, 1994) but because rural providers are suspicious of managed care, an urban-based phenomena (Kuder \& Colebaugh, 1996).

As for organizational determinants, the ownership, size, and case-mix within an organization are viewed as factors associated with choice of strategy (Bigelow \& Mahon, 1989; Gray, 1986;
Shortell, Morrison, \& Friedman, 1990; Zajac \& Shortell, 1989). Since all CHCs are not-for-profit or public agencies, we did not include ownership in the analysis. Size is important, because it is related to the organization's capacity to provide more services or diversify into other areas to utilize slack resources (Shortell, Morrison, Hughes, Friedman, and Vitek, 1987). Larger CHCs are more likely to be involved in managed care. We used total CHC staff, including providers of all types and administrative staff, to represent size. We chose to use "inputs" rather than "outputs" (i.e., patient volume), because inputs best represent the capacity for services, and empirical results indicate patient volume is a function of staff availability. The level of staffing dictates how many patients CHCs can see and the extent of the outreach work. The current need among underserved populations is significantly greater than the supply of professionals at CHCs. Since larger centers are in urban areas, where managed care hits first, we controlled for location (rural or urban) in the analysis. The lack of case-mix measures in the UDS limited our choice to the payermix variable only (i.e., proportion of Medicaid patients).

\section{Analysis}

In examining the relationship between CHCs' involvement in managed care and various center characteristics, we used chi-squares for categorical measures and ANOVA for interval-ratio measures. Post hoc means tests (Scheffe F) were performed on significant ANOVA results. To identify factors significantly associated with CHCs' involvement in managed care, we performed logistic regression analysis, with involvement in managed care as the dependent measure (coded 1 if yes and 0 if no) and state Section 1115 waiver status, percentage of revenue from grant funding, center size (measured by total center staff ), rural/urban location, and Medicaid patients as a proportion of total users as independent measures. Additional analyses were also conducted, including the performance of a Tobit 
Table 1. Patient characteristics

\begin{tabular}{|c|c|c|c|c|}
\hline & \multicolumn{4}{|c|}{ Managed care status } \\
\hline & $\begin{array}{l}\text { High volume, } \\
\text { high revenue } \\
\quad(n=178)\end{array}$ & $\begin{array}{l}\text { High volume, } \\
\text { low revenue } \\
\quad(n=91)\end{array}$ & $\begin{array}{l}\text { Low volume, } \\
\text { low revenue } \\
\quad(n=36)\end{array}$ & $\begin{array}{l}\text { Non-managed-care } \\
\quad(n=373)\end{array}$ \\
\hline Total users** & $15,531.7$ & $12,034.9$ & $15,258.0$ & $9,518.2$ \\
\hline Users under age 1 & $4.0 \%$ & $4.2 \%$ & $4.0 \%$ & $3.4 \%$ \\
\hline Users aged $1-14^{* *}$ & $29.4 \%$ & $27.2 \%$ & $28.2 \%$ & $25.2 \%$ \\
\hline Users aged $15-64^{* *}$ & $60.0 \%$ & $60.3 \%$ & $59.4 \%$ & $63.1 \%$ \\
\hline Users aged $65+^{* *}$ & $6.6 \%$ & $8.4 \%$ & $8.3 \%$ & $8.4 \%$ \\
\hline White ${ }^{* *}$ & $36.4 \%$ & $51.6 \%$ & $50.9 \%$ & $45.7 \%$ \\
\hline Black & $33.3 \%$ & $26.8 \%$ & $26.1 \%$ & $35.2 \%$ \\
\hline Hispanic (all races)* & $36.7 \%$ & $25.3 \%$ & $30.0 \%$ & $27.0 \%$ \\
\hline Asian/Pacific Islander & $8.2 \%$ & $6.4 \%$ & $1.4 \%$ & $3.8 \%$ \\
\hline American Indian & $3.7 \%$ & $3.5 \%$ & $1.1 \%$ & $3.8 \%$ \\
\hline $100 \%$ and below poverty line ${ }^{* *}$ & $60.2 \%$ & $49.7 \%$ & $52.3 \%$ & $53.3 \%$ \\
\hline $101-150 \%$ of poverty line* & $10.2 \%$ & $13.6 \%$ & $12.1 \%$ & $10.8 \%$ \\
\hline $151-200 \%$ of poverty line ${ }^{* *}$ & $5.9 \%$ & $7.3 \%$ & $5.6 \%$ & $4.8 \%$ \\
\hline Over $200 \%$ of poverty line** & $10.5 \%$ & $16.2 \%$ & $20.8 \%$ & $15.1 \%$ \\
\hline Homeless ${ }^{* *}$ & $3.2 \%$ & $2.5 \%$ & $7.0 \%$ & $14.6 \%$ \\
\hline Uninsured $^{* *}$ & $34.4 \%$ & $38.4 \%$ & $34.9 \%$ & $47.3 \%$ \\
\hline Medicaid $^{* *}$ & $35.5 \%$ & $28.4 \%$ & $32.3 \%$ & $25.7 \%$ \\
\hline Medicare $^{* *}$ & $6.5 \%$ & $9.0 \%$ & $9.7 \%$ & $9.6 \%$ \\
\hline Other public insurance ${ }^{* *}$ & $4.9 \%$ & $5.4 \%$ & $5.3 \%$ & $2.4 \%$ \\
\hline Private insurance* & $18.8 \%$ & $18.9 \%$ & $18.4 \%$ & $15.0 \%$ \\
\hline
\end{tabular}

Note: Differences among managed care status categories were evaluated by chi-square test for categorical variables and one-way analysis of variance for continuous variables.

${ }^{*} P<.05$.

** $P<.01$

model with different levels of involvement in managed care as a dependent measure and several OLS multiple regressions with proportion of revenue and users from managed care as dependent variables. These analyses yielded similar results and thus are not presented.

\section{Results}

\section{Managed care status and patient characteristics}

Table 1 shows the distribution of patients in CHCs arranged by level of involvement in managed care. Measured by total users, centers in- volved in managed care to some degree are significantly larger, averaging 12,035 to 15,532 users annually per center, compared with 9,518 users in a non-managed-care center. There are no significant differences between centers having different levels of managed care involvement.

Regarding patient age, there are proportionally more elderly patients and fewer pediatric patients in non-managed-care centers than HVHR centers ( $8.4 \%$ vs. $6.6 \%$ for patients 65 and older, $25.2 \%$ vs. $29.4 \%$ for patients $1-14 ; p<.05$ ). The result is largely due to the fact that there are proportionally more elderly patients ( 65 and older) in rural centers $(10 \%)$ than in urban centers $(5 \%)$. The 
observed differences across managed care centers are not statistically significant.

HVHR centers lead all CHCs in the proportion of patients of Hispanic origin $(36.7 \%$ vs. $27 \%$ for non-managed-care centers, $p<.05)$ and have the lowest proportion of white patients $(36.4 \%$ vs. $51.6 \%$ for HVLR centers and $45.7 \%$ for nonmanaged-care centers, $p<.05)$. Although rural centers have more white $(59.2 \%$ vs. $28.0 \%)$ and Hispanic patients $(33.1 \%$ vs. $26.8 \%)$ than urban centers, which have more black patients $(40.0 \%$ vs. $24.6 \%$ ), there is no significant difference in the proportion of black patients between managed care and non-managed-care centers

HVHR centers have proportionally more patients who are at or below the poverty line than other centers $(60.2 \%$ vs. $53.3 \%$ for nonmanaged-care centers and $51.6 \%$ for HVLR centers, $p<.05)$. The result is again influenced by patient distribution in rural and urban centers, since urban centers have proportionally more patients who are at or below the poverty line than rural centers $(65.5 \%$ vs. $45.2 \%)$. However, nonmanaged-care centers have proportionally more homeless users (14.6\% vs. $2.5-5 \%$ for managed care centers, $p<.05)$. This may be because homeless users are less likely to be insured.

In terms of insurance status, there are significantly more uninsured patients in non-managedcare centers than managed care centers $(47.3 \%$ vs. $34.4-38.4 \%, p<.05)$. Centers involved in managed care have proportionally more Medicaid and privately insured patients than those that are not $(28.4-5.5 \%$ vs. $25.7 \%$ for Medicaid, $18.4-18.9 \%$ vs. $15 \%$ for private insurance; $p<.05)$. Among managed care centers, there is a significant difference in Medicaid patients between HVHR centers and HVLR centers $(35.5 \%$ vs. $28.4 \%, p<.05)$.

\section{Managed care status and provider characteristics}

Table 2 displays the provider characteristics for CHCs arranged by level of involvement in managed care. Whether measured by total physicians, their patient encounters, other medical and dental professionals and their patient encounters, or total administrative staff, managed care centers are significantly larger, averaging 75.1-101 total staff, compared with 48.6 for non-managed-care centers. Among managed care centers, HVHR centers have significantly more staff, both medical and administrative, than other centers. However, the numbers of enabling services professionals (including case managers, education specialists, outreach workers, and transportation staff) are comparable among managed care centers (12.6-13.2 per center) although exceeding those in non-managed-care centers (7.2). Since rural centers are largely uninvolved in managed care, this finding reflects a rural-urban difference in funding history: enabling services are more likely to be funded in urban centers than rural ones, where a "leaner" model of care is practiced.

When measured by the number of patients seen by physicians, NPs, and PAs, no statistically significant differences are found between managed care and non-managed-care centers or across managed care centers. The reported differences in means reflect a small group of outliers. Dentists in non-managed-care centers are significantly more productive than those in managed care centers, seeing an average of 1,664-2,008 more patients annually $(p<.05)$.

\section{Managed care status and services provided}

There are few significant differences in the services offered by CHCs based on involvement in managed care. Most centers provide an array of primary care, obstetrical and prenatal care, dental care, and other professional services. Table 3 shows the service components of the various types of centers. In all cases, managed care centers are more likely to provide special medical and enabling services than non-managed-care centers. This may be explained by size. Since managed care centers are larger, they are more likely to provide a complete array of services than non-managed-care centers. 
Table 2. Provider characteristics

\begin{tabular}{|c|c|c|c|c|}
\hline & \multicolumn{4}{|c|}{ Managed care status } \\
\hline & $\begin{array}{l}\text { High volume, } \\
\text { high revenue } \\
\quad(n=178)\end{array}$ & $\begin{array}{l}\text { High volume, } \\
\text { low revenue } \\
\quad(n=91)\end{array}$ & $\begin{array}{l}\text { Low volume, } \\
\text { low revenue } \\
\quad(n=36)\end{array}$ & $\begin{array}{l}\text { Non-managed-care } \\
\quad(n=373)\end{array}$ \\
\hline \multicolumn{5}{|l|}{ Providers and staff } \\
\hline Family practitioners** & 3.4 & 3.0 & 3.6 & 1.9 \\
\hline General practitioners** & 2.6 & 1.0 & 1.1 & 1.2 \\
\hline Internists $^{* *}$ & 2.6 & 2.3 & 2.4 & 1.6 \\
\hline OB/GYN & 1.3 & 1.0 & 1.3 & 0.9 \\
\hline Pediatricians ${ }^{* *}$ & 2.8 & 2.1 & 2.5 & 1.7 \\
\hline Psychiatrists & 0.5 & 0.4 & 0.5 & 0.5 \\
\hline Other specialist physicians* & 0.8 & 0.6 & 0.3 & 0.4 \\
\hline Total physicians ${ }^{* *}$ & 8.7 & 6.5 & 7.3 & 4.2 \\
\hline $\begin{array}{l}\text { Nurse practitioners/physician } \\
\text { assistants** }\end{array}$ & 4.0 & 2.7 & 3.9 & 2.5 \\
\hline Nurses ${ }^{* *}$ & 11.7 & 8.4 & 9.3 & 6.2 \\
\hline $\begin{array}{l}\text { Total medical care services } \\
\text { personnel }^{* *}\end{array}$ & 38.7 & 26.4 & 32.5 & 18.3 \\
\hline Dentists** & 2.9 & 2.1 & 2.2 & 1.8 \\
\hline Total dental service personnel ${ }^{* *}$ & 8.5 & 6.3 & 6.3 & 5.0 \\
\hline Mental health specialists* & 3.6 & 2.7 & 2.3 & 1.9 \\
\hline Substance abuse specialists & 3.3 & 3.5 & 2.3 & 2.0 \\
\hline Pharmacy personnel** & 4.0 & 2.7 & 3.1 & 2.5 \\
\hline Case managers* & 4.5 & 3.3 & 5.4 & 3.2 \\
\hline Education specialists* & 3.9 & 3.2 & 4.8 & 2.4 \\
\hline Outreach workers* & 3.5 & 2.3 & 2.1 & 2.3 \\
\hline Transportation staff & 2.5 & 2.3 & 1.2 & 1.6 \\
\hline Total enabling services ${ }^{* *}$ & 13.2 & 12.6 & 12.8 & 7.2 \\
\hline Administration staff** & 18.5 & 14.9 & 15.5 & 9.3 \\
\hline Total staff** & 101.0 & 75.1 & 85.5 & 48.6 \\
\hline \multicolumn{5}{|l|}{ Encounters } \\
\hline Total physician encounters** & $33,933.7$ & $26,609.3$ & $29,486.4$ & $17,207.2$ \\
\hline Family practitioner encounters** & $13,171.9$ & $12,810.2$ & $14,359.0$ & $8,145.3$ \\
\hline General practitioner encounters** & $12,887.7$ & $3,647.9$ & $6,059.8$ & $4,579.9$ \\
\hline Internist encounters ${ }^{* *}$ & $9,597.9$ & $9,926.4$ & $8,666.6$ & $6,276.6$ \\
\hline OB/GYN encounters** & $4,642.5$ & $3,775.9$ & $6,771.5$ & $2,996.8$ \\
\hline Pediatrician encounters** & $10,901.4$ & $8,287.9$ & $9,260.9$ & $6,859.0$ \\
\hline Psychiatrist encounters & $1,130.2$ & $1,178.5$ & $1,287.9$ & 999.1 \\
\hline $\begin{array}{l}\text { Other specialist physician } \\
\text { encounters }\end{array}$ & $3,599.6$ & $1,576.1$ & $1,313.4$ & $1,607.6$ \\
\hline NP/PA encounters** & $10,270.7$ & $7,335.5$ & $11,607.4$ & $6,922.0$ \\
\hline $\begin{array}{l}\text { Total medical care services } \\
\text { personnel encounters** }\end{array}$ & $51,387.9$ & $36,790.0$ & $46,668.5$ & $26,974.0$ \\
\hline Dentist encounters** & $7,171.0$ & $5,394.5$ & $5,347.9$ & $4,334.5$ \\
\hline Total dental encounters** & $8,146.6$ & $6,021.0$ & $6,182.2$ & $4,969.3$ \\
\hline
\end{tabular}


Table 2. (continued)

\begin{tabular}{|c|c|c|c|c|}
\hline & \multicolumn{4}{|c|}{ Managed care status } \\
\hline & $\begin{array}{l}\text { High volume, } \\
\text { high revenue } \\
\quad(n=178)\end{array}$ & $\begin{array}{l}\text { High volume, } \\
\text { low revenue } \\
\quad(n=91)\end{array}$ & $\begin{array}{l}\text { Low volume, } \\
\text { low revenue } \\
\quad(n=36)\end{array}$ & $\begin{array}{l}\text { Non-managed-care } \\
\qquad(n=373)\end{array}$ \\
\hline \multicolumn{5}{|l|}{ Productivity } \\
\hline Total physician productivity & $3,889.5$ & $3,835.2$ & $6,128.7$ & $4,360.1$ \\
\hline NP/PA productivity & $2,625.0$ & $2,695.7$ & $2,912.4$ & $2,798.5$ \\
\hline $\begin{array}{c}\text { Total medical care services } \\
\text { personnel productivity* }\end{array}$ & $1,425.1$ & $1,492.5$ & $1,603.6$ & $1,573.3$ \\
\hline Dentist productivity* & $2,488.9$ & $2,531.6$ & $2,832.7$ & $4,496.9$ \\
\hline
\end{tabular}

Note: Differences among managed care status categories were evaluated by chi-square test for categorical variables and one-way analysis of variance for continuous variables.

${ }^{*} P<.05$.

${ }^{* *} P<.01$.

\section{Managed care status and financial characteristics}

Table 4 compares financial indicators among community health centers. Managed care centers are more likely to receive a variety of federal grants, including CHC Comprehensive Perinatal Care Program, Ryan White, and other BPHC grants, than non-managed-care centers, which might receive only $\mathrm{CHC}$ funding. However, the total grant revenue as a proportion of total revenue is significantly less in managed care than non-managed-care centers. Instead, managed care centers have a larger share of their revenue generated from services $(43.9-52.1 \%$ vs. $34.3 \%, p<.01)$ and thus they have higher "self-sufficiency" ratios than non-managed-care centers $(44-47.8 \%$ vs. $34.7 \%, p<.01)$. Among managed care centers, HVHR centers have significantly larger service revenue than HVLR centers $(52.1 \%$ vs. $43.9 \%, p<.05)$.

Managed care centers incur higher costs than non-managed-care centers. The average encounter cost ranges from $\$ 85.27$ to $\$ 95.41$ for managed care centers, compared with $\$ 82.90$ for non-managed-care centers $(p<.01)$. The average personnel and medical costs are highest in LVLR centers. However, these cost differentials are likely related to higher costs in urban areas. More managed care centers have deficits in net revenue in excess of $\$ 100,000$ (43.2\% of HVHR centers, $37.4 \%$ of HVLR centers, $33.4 \%$ of LVLR centers, and $24.9 \%$ in non-managed-care centers). Net revenue as a percentage of total revenue is more likely to be in deficit in managed care centers than non-managed-care centers $(-10.20 \%$ in HVHR centers, $-1.63 \%$ in HVLR centers, $-0.81 \%$ in LVLR centers, and $1.34 \%$ in nonmanaged-care centers). Thus, managed care centers are in a more vulnerable financial situation.

\section{Factors associated with CHCs' involvement in managed care}

Table 5 displays the results of a logistic regression model identifying the significant correlates associated with CHCs' involvement in managed care. As can be seen, Medicaid Section 1115 waiver status, a measure of external market forces, is highly significant: centers situated in waiver states are more than four times more likely to be involved in managed care than centers situated in states without the waiver. With respect to economic factors, external subsidy grant funding as a percentage of total revenue is inversely related to involvement in managed care. 
Table 3. Services directly provided

\section{Managed care status}

\begin{tabular}{cccc}
\hline High volume, & High volume, & Low volume, \\
high revenue & low revenue \\
$(n=178)$ & $(n=91)$ & $(n=36)$ & $(n=373)$
\end{tabular}

Primary medical care services

Urgent medical care*

24-hour coverage**

Family planning**

HIV testing**

Following hospitalized

patients**

OB/GYN care

Obstetrical care**

Prenatal care**

Antepartum fetal assessment*

Ultrasound $^{* *}$

Genetic counseling and testing*

Labor and delivery professional care**

Postpartum care**

Dental care services

Dental care-preventive**

Dental care-restorative**

Dental care-emergency*

Mental health/substance abuse services

24-hour crisis intervention/ counseling**

Other mental health services*

Other substance abuse services*

Other professional services

Hearing screening**

Nutrition services other than $\mathrm{WIC}^{* *}$

Pharmacy*

WIC services**

Enabling services

Discharge planning**

Employment/educational counseling*

Interpretation/translation services*
82.6

93.3

98.9

92.7

87.1

97.2

88.2

66.9

41.6

25.3

50.0

86.0

75.3

69.1

66.3

24.7

32.0

33.7

86.5

82.6

68.0

53.9

52.8

25.3

78.7
85.7

96.7

100.0

85.7

86.8

94.5

87.9

61.5

33.0

17.6

50.5

84.6

72.5

52.7

56.0

16.5

24.2

28.6

92.3

81.3

63.7

40.7

49.5

23.1

76.9
91.7

91.7

94.4

83.3

88.9

94.4

87.7

80.6

55.6

68.4

46.1

30.6

21.7

13.9

15.8

52.8

30.8

65.7

62.5

72.2

48.5

63.9

52.8

66.7

11.1

11.3

19.4

21.4

13.9

23.1

75.6

71.3

86.1

60.3

35.1

38.9

39.1

20.6

$2.8 \quad 20.6$

72.2

66.5

Note: Differences among managed care status categories were evaluated by chi-square test for categorical variables and one-way analysis of variance for continuous variables.

${ }^{*} P<.05$.

${ }^{* *} P<.01$ 
Table 4. Financial characteristics

\begin{tabular}{|c|c|c|c|c|}
\hline & \multicolumn{4}{|c|}{ Managed care status } \\
\hline & $\begin{array}{l}\text { High volume, } \\
\text { high revenue } \\
\quad(n=178)\end{array}$ & $\begin{array}{l}\text { High volume, } \\
\text { low revenue } \\
(n=91)\end{array}$ & $\begin{array}{l}\text { Low volume, } \\
\text { low revenue } \\
\quad(n=36)\end{array}$ & $\begin{array}{l}\text { Non-managed-care } \\
\quad(n=373)\end{array}$ \\
\hline \multicolumn{5}{|l|}{$\begin{array}{l}\text { Bureau of Primary Health } \\
\text { Care (BPHC) funding }\end{array}$} \\
\hline $\begin{array}{l}\text { Community Health Center } \\
\text { (Section 330)** }\end{array}$ & $96.6 \%$ & $100.0 \%$ & $94.4 \%$ & $80.7 \%$ \\
\hline $\begin{array}{l}\text { Comprehensive Perinatal } \\
\text { Care Program** }\end{array}$ & $41.6 \%$ & $41.8 \%$ & $41.7 \%$ & $21.2 \%$ \\
\hline $\begin{array}{l}\text { Ryan White Title IIIb HIV } \\
\text { Early Intervention** }\end{array}$ & $18.0 \%$ & $13.2 \%$ & $16.7 \%$ & $8.6 \%$ \\
\hline Other BPHC Resources** & $9.0 \%$ & $13.2 \%$ & $5.6 \%$ & $3.8 \%$ \\
\hline Self-sufficiency** & $47.8 \%$ & $44.0 \%$ & $47.1 \%$ & $34.7 \%$ \\
\hline Grant revenue** & $44.2 \%$ & $44.4 \%$ & $42.1 \%$ & $54.1 \%$ \\
\hline Service revenue** & $52.1 \%$ & $43.9 \%$ & $46.3 \%$ & $34.3 \%$ \\
\hline \multicolumn{5}{|l|}{ Net revenue** } \\
\hline More than $\$ 500,000$ & $10.7 \%$ & $8.8 \%$ & $5.6 \%$ & $7.8 \%$ \\
\hline$\$ 100,000$ to $\$ 500,000$ & $18.5 \%$ & $22.0 \%$ & $36.1 \%$ & $19.6 \%$ \\
\hline$\$ 0$ to $\$ 99,999$ & $18.0 \%$ & $14.3 \%$ & $11.1 \%$ & $29.8 \%$ \\
\hline$-\$ 1$ to $-\$ 99,999$ & $9.6 \%$ & $17.6 \%$ & $13.9 \%$ & $18.0 \%$ \\
\hline$-\$ 100,000$ to $-\$ 500,000$ & $21.9 \%$ & $29.7 \%$ & $16.7 \%$ & $19.0 \%$ \\
\hline Less than $-\$ 500,000$ & $21.3 \%$ & $7.7 \%$ & $16.7 \%$ & $5.9 \%$ \\
\hline Average encounter cost** & $\$ 91.6$ & $\$ 95.4$ & $\$ 85.3$ & $\$ 82.9$ \\
\hline Average medical encounter cost* & $\$ 56.5$ & $\$ 59.0$ & $\$ 53.3$ & $\$ 50.2$ \\
\hline Average enabling services cost & $\$ 163.6$ & $\$ 136.9$ & $\$ 170.9$ & $\$ 157.4$ \\
\hline Average personnel cost* & $\$ 59,761.9$ & $\$ 61,542.7$ & $\$ 80,919.1$ & $\$ 58,744.8$ \\
\hline Average medical $\operatorname{cost}^{* *}$ & $\$ 72,389.5$ & $\$ 78,514.4$ & $\$ 95,627.5$ & $\$ 71,723.9$ \\
\hline Average administrative cost & $\$ 100,411.1$ & $\$ 94,233.1$ & $\$ 120,284.5$ & $\$ 100,457.8$ \\
\hline
\end{tabular}

Note: Differences among managed care status categories were evaluated by chi-square test for categorical variables and one-way analysis of variance for continuous variables.

$* P<.05$.

${ }^{* *} P<.01$.

Centers that rely less on subsidy grants and more on Medicaid are more likely to seek involvement in managed care. As for location, rural centers are nearly half as likely to get involved in managed care as urban centers.

In terms of organizational determinants, the percentage of users who are Medicaid recipients is the most significant correlate of managed care experience. A $10 \%$ or greater proportion of Medicaid users is associated with 1.12 times the odds of involvement in managed care. The size of the center, as measured by total center staff, is also significantly associated with involvement in managed care.

\section{DISCUSSION}

$\mathrm{CHCs}$ are becoming increasingly involved in managed care. While it is premature to assess the 
Table 5. Logistic regression: significant correlates associated with community health centers' involvement in managed care (dependent measure: primary care $[$ managed care $=1$; non-managed-care $=0]$ )

\begin{tabular}{|c|c|c|c|c|c|}
\hline Variables & $\boldsymbol{B}$ & S.E. & Wald & $P$-value & Odds Ratio \\
\hline Constant & .3168 & .5425 & .3409 & .5593 & \\
\hline Medicaid 1115 waiver & 1.4508 & .2755 & 27.7336 & .0000 & 4.2667 \\
\hline Rural/urban (default) & -.4677 & .1940 & 5.8121 & .0159 & .6265 \\
\hline $\begin{array}{l}\text { Percentage of users who were } \\
\text { medicaid members }\end{array}$ & 1.1003 & .5665 & 3.7727 & .0521 & 3.0050 \\
\hline Percentage of grant revenue & -1.7604 & .4509 & 15.2420 & .0001 & .1720 \\
\hline Total center staff & .0088 & .0016 & 29.1182 & .0000 & 1.0088 \\
\hline
\end{tabular}

impact of managed care on CHCs given its relatively short history, policy makers must quickly find out what are the likely consequences of managed care. Timely knowledge of warning signs that CHCs' ability to fulfill their mission of providing access to health care for medically underserved populations might be compromised can alert policy makers to the need for and suggest types of policy interventions. Our study compared CHCs with different levels of managed care involvement on a number of patient, provider, services, and financial characteristics. Although the cross-sectional nature of the data and analysis does not allow us to establish causal relationships, these comparisons help identify the differences between and similarities of CHCs with different levels of managed care involvement. Knowledge of these differences and similarities can help identify the likely impact of managed care and enable us to design a more in-depth longitudinal analysis in order to establish causal relationships.

\section{Potential influences of managed care}

There are indications that centers involved in managed care have more diversified sources of revenue and depend less on grant funding. They are more likely to obtain a variety of BPHC funding than non-managed-care centers, which might receive only $\mathrm{CHC}$ funding.

However, this does not suggest that CHCs' reliance on grant support is reduced as a result of managed care. CHCs would still need significant grant support to continue to serve those who are uninsured or medically indigent. Indeed, our findings indicate that CHCs involved in managed care have served a significantly smaller proportion of uninsured patients (34.4-38.4\%) and homeless patients $(2.5-7 \%)$ than CHCs not involved in managed care $(47.3 \%$ and $14.6 \%$, respectively). Although it is unclear whether involvement in managed care led to a reduction in services to the uninsured and homeless or whether having a lower proportion of uninsured and homeless and a higher proportion of insured patients led to easier acceptance of managed care, it is certain that prepaid or capitation-based managed care does not reward cross-subsidization or uncompensated care (Dubay, Norton, \& Moon, 1995; Mann, Melnick, Bamezai, and Zwanziger, 1995; Weissman, 1996). Greater and continued involvement in managed care is expected to reduce CHCs' capacity to provide uncompensated care despite their willingness and stated mission to do so.

Consistent with a recent case study on CHCs' experience with prepaid managed care (GAO, 1995), our study confirms the financial vulnerability of centers participating in prepaid managed care. Managed care centers are more likely to have deficits than non-managed-care centers (47.2\% of the low-volume managed care centers, $54.9 \%$ of the high-volume managed care centers, and $42.8 \%$ of non-managed-care centers). 
Involvement in managed care is also positively associated with both the amount and proportion of the deficits. The cash flow problem identified by case studies of CHCs may well account for the deficits (Finkler, Knickman, \& Hanson, 1994; GAO, 1995). Another potential cause is the higher costs incurred by managed care centers. The average encounter cost is \$2.37-\$12.51 higher in managed care centers than in non-managed-care centers. It is likely that part of the additional costs is related to managed care involvement, for such involvement requires the development of new organizational skills and the enhancement of the management information system, the financial management system, and patient management techniques (Abrams et al., 1995; Buchanan, Lindsey, Leibowitz, and Davies, 1992). New systems and administrative demands generated by managed care will likely cost, rather than save, money, at least in the short run (Gold, Sparer, \& Chu 1996). Under managed care, centers may be required to pay for a broader range of services. Although the magnitude of the deficit may also be related to the size of the facility, and deficits as a proportion of total revenue are relatively small, continued financial strain as a result of reduced payment from Medicaid managed care and higher operating costs heighten concern about the ability of CHCs to sustain their commitment to providing uncompensated care.

Our study demonstrates that dental staff in managed care centers are less productive than those in non-managed-care centers. Providers see fewer patients in managed care centers than in non-managed-care centers. One explanation for this is that managed care provides an incentive to reduce visits, since additional visits would not lead to additional revenue (Rodwin, 1995; Schroeder, Clarke, \& Webster, 1985). Another possible explanation is that providers in managed care centers have to spend more hours on activities unrelated to patient care. A recent national survey of medical directors at $\mathrm{CHCs}$ indicates that medical directors at urban centers, where managed care involvement is more prevalent, spent significantly less hours on patient care than those at rural centers, which have limited managed care involvement (20.31 vs. 23.91 hours per week) (Shi, Samuels, Cochran, Glover, and Singh, 1998).

The concern that CHCs involved in managed care would not continue to provide patients with nonreimbursable services under managed care, such as enabling and culturally sensitive services, is not supported by our findings. Regardless of managed care involvement, $\mathrm{CHCs}$ have so far maintained their commitment to the provision of these services. However, whether they can sustain their efforts remains to be seen.

Among managed care centers, we are interested in the comparison between HVHR and HVLR centers - in particular, in how low revenue has affected the performance of the HVLR centers. HVHR centers draw a significantly higher portion of their revenue from services than do HVLR centers ( $52.1 \%$ vs. $43.9 \%)$. HVHR centers have proportionally more Medicaid patients and fewer uninsured patients than HVLR centers $(35.5 \%$ vs. $28.4 \%$ and $34.4 \%$ vs. $38.4 \%$, respectively). The medical encounter cost is significantly higher in HVLR centers than in HVHR centers (\$95.41 vs. \$91.65). The average personnel and medical costs are higher in HVLR than HVHR centers. A significant proportion of both HVLR and HVHR centers have net revenue deficits $(55.0 \%$ vs. $52.8 \%)$.

\section{Correlates of CHCs' involvement in managed care}

In addition to examining the influence of managed care on $\mathrm{CHCs}$, the study also identified factors significantly associated with CHCs' involvement in managed care. The results indicate that both external and internal factors contributed to CHCs' involvement in managed care. Externally, the most dominant factor is Medicaid Section 1115 waiver status. When states mandate that their Medicaid patients enroll in managed care, $\mathrm{CHCs}$ have to get involved in managed care or risk losing the Medicaid patients and the associated revenue. External funding source is critical: centers with proportionally less grant funding are 
more likely to get involved in managed care. Rural location is also significantly but inversely related to involvement in managed care. Many observed patient differences between managed care and non-managed-care centers can be explained by location-related characteristics. Rural centers have proportionally more elderly, white, and Hispanic patients, whereas urban centers have proportionally more black patients and patients who are at or below the poverty line. These findings are consistent with the open system model, which emphasizes the resource dependency of organizations on their environment (Hannan \& Freeman, 1977; Scott, 1987).

The most dominant internal factor is the proportion of a center's Medicaid users. Centers with proportionally more Medicaid users are more likely to get involved in managed care, perhaps out of a strategic need to retain or expand the patient and revenue base. The size of the center also matters. Whether measured by providers, administrators, services, revenues, users, or encounters, managed care centers are significantly larger, averaging 75.1-101 total staff per center, compared with 48.6 in non-managed-care centers. Indeed, the logistic regression model indicates that size is a significant predictor of CHCs' involvement in managed care. Larger CHCs have larger service capacity and are more likely to be adversely affected by slack resources. Getting involved in managed care may well be a strategy chosen by centers to utilize this capacity or avoid the prospect of underutilizing this capacity. This finding is consistent with strategic decision making by other health services organizations (Bigelow \& Mahon, 1989; Ginn \& Young, 1992).

This study is limited by the data collected annually from the centers and by the availability of secondary data. For example, CHCs' involvement in managed care is likely to be influenced by other external and internal factors, such as community characteristics, availability of managed care, administrator characteristics, the influence of the board, and the culture of the center. Likewise, in addition to managed care, CHCs' outcomes are also influenced by other factors, such as community characteristics (e.g., populations served), management characteristics, and practice characteristics. Future attention to these other variables could help inform the analysis.

Several terms used in the analyses are incomplete or imprecise. For example, we are unable to characterize the types of managed care arrangement a center is involved in (e.g., an HMO, a PPO, or some other arrangement). Although from earlier case studies we know that four major models of $\mathrm{CHC}$ participation in the prepaid environment have emerged, we do not know which model is adopted by a particular center. Failure to differentiate the managed care models will make the assessment of managed care impact incomplete. We use productivity and average cost indicators as measures of a center's performance. But these measures are imprecise and can be explained by other factors (e.g., case mix or outcomes). Moreover, centers that fulfill their mission by serving the uninsured are by definition less selfsufficient. Centers with lower productivity may be doing a better job by either taking more time with patients or doing a better preventive work so that patients visit them less frequently. In either case, lower productivity actually indicates better performance than higher productivity. Similarly, centers with higher average costs might produce higher quality services. Future studies might focus on more sensitive information from all or a representative sample of centers with different types of managed care and different case mixes.

This study does enable us, nonetheless, to make some important points. It suggests that CHCs' involvement in managed care is largely in response to external market pressuresMedicaid managed care and the prospect of reduced federal grant funding. However, involvement in managed care is associated with greater financial vulnerability reflected in higher costs and net revenue deficits. With modest budgets, limited experience in dealing with managed care, and the mission to serve all regardless of ability 
to pay, $\mathrm{CHCs}$ that choose managed care participation face great challenges. Yet if $\mathrm{CHCs}$ are unable to preserve their paying Medicaid patient base, they risk even greater losses in revenue and consequently the capacity to extend care to the indigent.

\section{REFERENCES}

Abrams, R., Savela, T., Trinity, M.T., Falik, M., Tutunjian, B., \& Ulmer, C. (1995). Performance of community health centers under managed care. Journal of Ambulatory Care Management, 18(3), 77-88.

Alpha Center. (1995, Jan.-Feb.). More for less?: Increasing insurance coverage through Medicaid waiver programs. State Initiatives in Health Care Reform, 10, 1-3.

Bigelow, B., \& Mahon, J. (1989). Strategic behavior of hospitals: A framework for analysis. Medical Care Review, 46, 295-311.

Buchanan, J.L., Lindsey, P.A., Leibowitz, A., \& Davies, A.R. (1992). HMOs for Medicaid: The road to financial independence is often poorly paved. Journal of Health Politics, Policy, and Law, 17(1), 71-96.

Bureau of Primary Health Care. (1995). User manual: Uniform data system. Bethesda, MD: Author.

Dubay, L.C., Norton, S.A., \& Moon, M. (1995). Medicaid expansions for pregnant women and infants: Easing hospitals' uncompensated care burdens? Inquiry, 32, 332-344.

Employee Benefits Research Institute. (1995). Sources of health insurance and characteristics of the uninsured: Analysis of the March 1994 current population survey (EBRI Special Report SR-28, Issue Brief No. 158). Washington, DC: Author.

Ermann, D., \& Richmond, J. (1994). Managed care arrangements: Barriers to cost savings potential. Medical Care Review, 51, 125-148.

Feldman, R., Dietz, D., \& Brooks, E.F. (1978). The financial viability of rural primary health care centers. American Journal of Public Health, 68, 981-988.

Feldman, R., Kralewski, J., \& Qowd, B. (1989). Health maintenance organization: The beginning or the end? Health Services Research, 24, 191-211.

Finkler, S.A., Knickman, J.R., \& Hanson, K.L. (1994). Improving the financial viability of primary care health centers. Hospitals and Health Services Administration, 39, 117-131.

Frech, H.E., \& Ginsburg, P.B. (1974). Optimal scale in medical practice: A survival analysis. Journal of Business, 47(1): 23-36.

Ginn, G.O., \& Young, G.J. (1992). Organizational and environmental determinants of hospital strategy. Hospital and Health Services Administration, 37, 291-302.
Gold, M.R. (1991, Winter). HMOs and managed care. Health Affairs, 189-206.

Gold, M., Sparer, M., \& Chu, K. (1996, Fall). Medicaid managed care: Lessons from five states. Health Affairs, 153-166.

Golladay, F.L., Manser, M.E., \& Smith, K.R. (1974). Some economics in the delivery of medical care: A mixed integer programming analysis of efficient manpower utilization. Journal of Human Behavior, 9(1), 50-62.

Gray, B. (Ed.). (1986). For-profit enterprise in health care. Washington, DC: National Academy Press.

Hadley, J., Mullner, R., \& Feder, J. (1982). The financially distressed hospital. New England Journal of Medicine, 307, 1283-1287.

Hannan, M.T., \& Freeman, J. (1977). The population ecology of organizations. American Journal of Sociology, 82, 929-964.

Health Care Financing Administration, Office of Managed Care. (1996). Medicaid managed care enrollment report. Washington, DC: U.S. Government Printing Office.

Health Services Research Center, University of North Carolina. (1983). National evaluation of rural primary health care programs (Report to the Robert Wood Johnson Foundation). Chapel Hill, NC: University of North Carolina.

Henderson, T., \& Markus, A.R. 1996. Medicaid managed care: How do community health centers fit? Health Care Financing Review, 17, 135-142.

Hoy, E.W., Curtis, R.E., \& Rice, T. (1991, Winter). Change and growth in managed care. Health Affairs, 18-36.

Iglehart, J.K. (1992). The American health care system: Managed care. New England Journal of Medicine, 331, 63-67.

Iglehart, J.K. (1994). The struggle between managed care and fee-for-service practice. New England Journal of Medicine, 327, 742-747.

Kilstein, S.M., Sanders, C.R., \& Schieber, G.J. (1980). An analysis of hospital financial distress. Journal of Contemporary Business, 9(4), 55-66.

Kronick, R., Goodman, D.C., Wennberg, J., \& Wagner, E. (1993). The marketplace in health care reform: The demographic limitations of managed competition. New England Journal of Medicine, 328, 148-152. 
Kuder, J.M., \& Colebaugh, J.B. (1996). A provisional framework for the economic analysis of managed care development in rural areas (New York Rural Health Research Center Working Paper No. 12). Buffalo, NY: State University of New York at Buffalo, Department of Family Medicine.

Lewin VHI and MDS Associates. (1994). Community health centers' performance under managed care. Bethesda, MD: Health Resources and Services Administration, Bureau of Primary Health Care.

Lewis-Idema, D., Chu, R., Hughes, R., \& Lefkowitz, B. (1998). FQHC: Harnessing the incentives of cost reimbursement. Journal of Ambulatory Care Management, 21(2), 58-75.

Mann, J., Melnick, G., Bamezai, A., \& Zwanziger, J. (1995, Spring). Uncompensated care: Hospitals' responses to fiscal pressures. Health Affairs, 263-270.

Mullner, R.M., Rydman, R.J., Whiteis, D.G., \& Rich, R.F. (1989). Rural community hospitals and factors correlated with their risk of closing. Public Health Reports, 104, 315-325.

Mullner, R.M. (1990). Rural hospital survival: An analysis of facilities and services correlated with risk of closure. Hospital and Health Services Administration, 35, 121-137.

Oliver, T.R. (1998). The collision of economics and politics in Medicaid managed care: Reflections on the course of reform in Maryland. The Milbank Quarterly, 76(1), 1-43.

Porter, M.E. (1980). Competitive strategy: Techniques for analyzing industries and competitors. New York: The Free Press.

Rodwin, M.A. (1995). Conflicts in managed care. New England Journal of Medicine, 332, 604-607.

Rosenblatt, R.A., \& Moscovice, I. (1978). The growth and evolution of rural primary care practice: The national health service corps experience in the Northwest. Medical Care, 16, 819-827.

Rosenblatt, R.A., \& Moscovice, I. (1982). Rural health care. New York: Wiley.

Samuels, M.E., \& Shi, L. (1992). Survey of community and migrant health centers regarding utilization of nurse practitioners, physicians assistants, and certified nurse midwives. Kansas City, MO: National Rural Health Association.

Schroeder, J.L., Clarke, J.T., \& Webster, J.R. (1985).
Prepaid entitlements: A new challenge for physicianpatient relationship. JAMA, 254, 3080-3082.

Scott, W.R. (1987). Organizations: Rational, natural, and open systems. Englewood Cliffs, NJ: Prentice Hall.

Shi, L., Samuels, M.E., Konrad, T.R., Porter, C.Q., Stoskopf, C.H., \& Richter, D.L. (1994). Rural primary care program survival: An analysis of financial variables. Journal of Rural Health, 10, 173-182.

Shi, L., Samuels, M.E., Cochran, C., Glover, S., \& Singh, D.A. (1998). Physician practice characteristics and satisfaction: A rural-urban comparison of medical directors at U.S. community and migrant health centers. Journal of Rural Health.

Shortell, S.M., Morrison, E.M., \& Friedman, B.S. (1990). Strategic choices for America's hospitals: Managing change in turbulent times. San Francisco: JosseyBass.

Shortell, S.M., Morrison, E.M., Hughes, S.L., Friedman, B.S., \& Vitek, J.L. (1987). Diversification of the health care services: The effects of ownership, environment, and strategy. In R.M. Scheffler \& L.F. Rossiter (Eds.), Advances in Health Economics and Health Services Research. Greenwich, CT: JAI Press.

U.S. Congress, Office of Technology Assessment. (1990). Health Care in Rural America, OTA-H-434. Washington, DC: U.S. Government Printing Office.

U.S. General Accounting Office. (1995). Community health centers: Challenges in transitioning to prepaid managed care (GAO/HEHS Publication No. 95-138). Washington, DC: Author.

Walleck, S.S., \& Kretz, S.E. (1981). Rural medicine: Obstacles and solutions for self-sufficiency. Lexington, MA: Lexington Books.

Weissman, J. (1996). Uncompensated hospital care: Will it be there if we need it? JAMA 276, 823-828.

Wellever, A., \& Deneen, V. (1994). Managed health care reform and rural areas: Literature review and synthesis (AHCPR Rural Center Contract Report). Minneapolis, MN: University of Minnesota.

Zajac, E.J., \& Shortell, S.M. (1989). Changing generic strategies: Likelihood, direction, and performance implications. Strategic Management Journal, 10, 413-430.

Zarabozo, C., Taylor, C., \& Hicks, J. (1996). Medicare managed care: Numbers and trends. Health Care Financing Review, 17, 243-261. 


\section{Appendix A}

\section{Definitions and Descriptive Statistics}

Table 1 Variables used in study analysis

\begin{tabular}{|c|c|c|}
\hline Variable name & Definition & $\begin{array}{c}\text { Mean (stnd dev.) } \\
\text { Number (percentage) }\end{array}$ \\
\hline Rural/urban status & $\begin{array}{l}\text { Community health centers designated } \\
\text { as rural or urban }\end{array}$ & \\
\hline Urban & & $315(46.3 \%)$ \\
\hline Rural & & $366(53.7 \%)$ \\
\hline Service sites & $\begin{array}{l}\text { Number of service sites per } \\
\text { community health center }\end{array}$ & $2.9(2.1)$ \\
\hline $\begin{array}{r}\text { Medicaid } 1115 \\
\text { waiver states }\end{array}$ & $\begin{array}{l}\text { Community health centers located } \\
\text { in states that implemented } \\
\text { Medicaid } 1115 \text { waiver } \\
\text { program by } 1996\end{array}$ & $83(12.2 \%)$ \\
\hline \multicolumn{3}{|l|}{ Patient characteristics } \\
\hline Total users & $\begin{array}{l}\text { Total community health center users in } \\
1996\end{array}$ & $11,825.4(11,360.4)$ \\
\hline Users under age 1 & $\begin{array}{l}\text { Percentage of community health center } \\
\text { users under age } 1 \text { in } 1996\end{array}$ & $3.7 \%(2.9 \%)$ \\
\hline Users aged 1-14 & $\begin{array}{l}\text { Percentage of community health center } \\
\text { users between age } 1 \text { and age } 14 \\
\text { in } 1996\end{array}$ & $26.7 \%(9.7 \%)$ \\
\hline Users aged $15-64$ & $\begin{array}{l}\text { Percentage of community health center } \\
\text { users between age } 15 \text { and age } 64 \text { in } 1996\end{array}$ & $61.7 \%(11.4 \%)$ \\
\hline Users aged $65+$ & $\begin{array}{l}\text { Percentage of community health center } \\
\text { users aged } 65 \text { and older in } 1996\end{array}$ & $7.9 \%(6.1 \%)$ \\
\hline White & $\begin{array}{l}\text { Community health center users who } \\
\text { are white and not Hispanic }\end{array}$ & $44.5 \%(33.3 \%)$ \\
\hline Black & $\begin{array}{l}\text { Community health center users who are } \\
\text { black and not Hispanic }\end{array}$ & $33.0 \%(30.3 \%)$ \\
\hline Hispanic & $\begin{array}{l}\text { Community health center users who are } \\
\text { Hispanic, including all races }\end{array}$ & $29.6 \%(32.4 \%)$ \\
\hline Asian/Pacific Islander & $\begin{array}{l}\text { Community health center users who are } \\
\text { Asian/Pacific Islanders }\end{array}$ & $5.4 \%(16.2 \%)$ \\
\hline American Indian & $\begin{array}{l}\text { Community health center users who are } \\
\text { American Indians or Alaska Natives }\end{array}$ & $3.6 \%(9.6 \%)$ \\
\hline $100 \%$ and below poverty line & $\begin{array}{l}\text { Community health center users whose } \\
\text { family income is } 100 \% \text { of poverty } \\
\text { line or below }\end{array}$ & $54.6 \%(27.2 \%)$ \\
\hline $101-150 \%$ of poverty line & $\begin{array}{l}\text { Community health center users whose } \\
\text { family income is } 101-150 \% \\
\text { of poverty line }\end{array}$ & $11.1(9.7 \%)$ \\
\hline
\end{tabular}


Table 1. (Continued)

\begin{tabular}{|c|c|c|}
\hline Variable name & Definition & $\begin{array}{l}\text { Mean (stnd dev.) } \\
\text { Number (percentage) }\end{array}$ \\
\hline $151-200 \%$ of poverty line & $\begin{array}{l}\text { Community health center users whose family } \\
\text { income is } 151-200 \% \text { of poverty line }\end{array}$ & $5.5 \%(6.8 \%)$ \\
\hline Over $200 \%$ of poverty line & $\begin{array}{l}\text { Community health center users } \\
\text { whose family income is over } \\
200 \% \text { of poverty line }\end{array}$ & $14.3 \%(20.0 \%)$ \\
\hline Homeless & $\begin{array}{l}\text { Community health center users } \\
\text { who are homeless }\end{array}$ & $\begin{array}{r}2,092.9(2,936.4) \\
9.6 \%(27.1 \%)\end{array}$ \\
\hline Uninsured & $\begin{array}{l}\text { Percentage of community health center } \\
\text { users with no health insurance } \\
\text { coverage }\end{array}$ & $42.1 \%(21.0 \%)$ \\
\hline Medicaid & $\begin{array}{l}\text { Percentage of community health center } \\
\text { users with Medicaid (Title XIX) } \\
\text { coverage }\end{array}$ & $29.0 \%(17.0 \%)$ \\
\hline Medicare & $\begin{array}{l}\text { Percentage of community health } \\
\text { center users with Medicare (Title } \\
\text { XVIII) coverage }\end{array}$ & $8.7(7.3 \%)$ \\
\hline Other public insurance & $\begin{array}{l}\text { Percentage of community health } \\
\text { center users with other public } \\
\text { insurance coverage }\end{array}$ & $3.6 \%(8.5 \%)$ \\
\hline Private insurance & $\begin{array}{l}\text { Percentage of community health } \\
\text { center users with private insurance } \\
\text { coverage }\end{array}$ & $16.7 \%(15.8 \%)$ \\
\hline \multicolumn{3}{|l|}{ Provider characteristics } \\
\hline Total physicians & $\begin{array}{l}\text { Community health center physicians, } \\
\text { including family practitioners, } \\
\text { general practitioners, internists, } \\
\text { obstetricians/gynecologists, pediatricians, } \\
\text { psychiatrists, and other specialist physicians }\end{array}$ & $5.9(6.5)$ \\
\hline Physician productivity & $\begin{array}{l}\text { Average } 1996 \text { encounters } \\
\text { per physician (total } 1996 \\
\text { physician encounters } \div \text { total physicians) }\end{array}$ & $4,257.5(4,834.8)$ \\
\hline $\begin{array}{l}\text { Nurse practitioners/ } \\
\text { physician assistants }\end{array}$ & $\begin{array}{l}\text { Community health center nurse } \\
\text { practitioners and physician assistants }\end{array}$ & $3.0(3.1)$ \\
\hline NP/PA productivity & $\begin{array}{l}\text { Average } 1996 \text { encounters per nurse } \\
\text { practitioner/physician assistant } \\
\text { (total } 1996 \text { NP/PA encounters } \div \text { total } \\
\text { NP/PA) }\end{array}$ & $2,744.3(1,006.6)$ \\
\hline $\begin{array}{l}\text { Total medical care } \\
\text { services personnel }\end{array}$ & $\begin{array}{l}\text { Nurse practitioners/physician assistants, } \\
\text { certified nurse midwives, nurses, other } \\
\text { medical personnel, laboratory personnel, } \\
\text { and X-ray personnel }\end{array}$ & $25.6(26.8)$ \\
\hline
\end{tabular}


Table 1. (Continued)

\begin{tabular}{|c|c|c|}
\hline Variable name & Definition & $\begin{array}{l}\text { Mean (stnd dev.) } \\
\text { Number (percentage) }\end{array}$ \\
\hline $\begin{array}{l}\text { Total medical care } \\
\text { productivity }\end{array}$ & $\begin{array}{l}\text { Average } 1996 \text { encounters per total medical care } \\
\text { services personnel (total } 1996 \text { medical care } \\
\text { encounters } \div \text { total medical care services } \\
\text { personnel) }\end{array}$ & $1,523.8(597.2)$ \\
\hline Dentists & Community health center dentists & $2.2(2.0)$ \\
\hline Dentist productivity & $\begin{array}{l}\text { Average } 1996 \text { encounters per dentist (total } 1996 \\
\text { dentist encounters } \div \text { total dentists) }\end{array}$ & $3,508.6(17,783.5)$ \\
\hline $\begin{array}{l}\text { Total dental services } \\
\text { personnel }\end{array}$ & $\begin{array}{l}\text { Community health center dentists, dental } \\
\text { hygienists, dental assistants, aides, and } \\
\text { technicians }\end{array}$ & $6.3(6.0)$ \\
\hline Total enabling services & $\begin{array}{l}\text { Community health center personnel } \\
\text { performing enabling service activities, } \\
\text { including case management, outreach, } \\
\text { transportation, and other }\end{array}$ & $9.9(16.5)$ \\
\hline Administration staff & Community health center administration staff & $12.8(14.3)$ \\
\hline Total staff & $\begin{array}{l}\text { Total community health center staff, including } \\
\text { providers and administrative staff }\end{array}$ & $68.0(69.5)$ \\
\hline \multicolumn{3}{|l|}{ Financial characteristics } \\
\hline Self-sufficiency & $\begin{array}{l}\text { Self-sufficiency ratio }=\text { total third-party } \\
\text { payments (patient collections }+ \\
\text { Medicaid }+ \text { Medicare }+ \text { other public } \\
\text { insurance }+ \text { other private insurance) } \div \\
\text { total calendar year costs }\end{array}$ & $40.1 \%(20.0 \%)$ \\
\hline Grant revenue & $\begin{array}{l}\text { The percentage of total revenues that } \\
\text { come from federal, state, local, and } \\
\text { private grants (total BHEC grants }+ \\
\text { total other federal grants }+ \text { total } \\
\text { nonfederal grants or contracts) } \div \\
\text { total revenue }\end{array}$ & $49.5 \%(25.6 \%)$ \\
\hline Service revenue & $\begin{array}{l}\text { The percentage of total revenues that come } \\
\text { from payments (total third-party } \\
\text { revenue } \div \text { total revenue) }\end{array}$ & $40.9 \%(27.0 \%)$ \\
\hline \multirow[t]{7}{*}{ Net revenue } & Total revenue - total calendar year costs & \\
\hline & More than $\$ 500,000$ & $58(8.6 \%)$ \\
\hline & $\$ 100,000$ to $\$ 500,000$ & $139(20.5 \%)$ \\
\hline & $\$ 0$ to $\$ 99,999$ & $160(23.6 \%)$ \\
\hline & $-\$ 1$ to $-\$ 99,999$ & $105(15.5 \%)$ \\
\hline & $-\$ 100,000$ to $-\$ 500,000$ & $143(21.1 \%)$ \\
\hline & Less than $-\$ 500,000$ & $73(10.8 \%)$ \\
\hline $\begin{array}{l}\text { Average encounter } \\
\text { cost }\end{array}$ & $\begin{array}{l}\text { Total calendar year costs } \div \text { total } \\
\text { staffing encounters }\end{array}$ & $\$ 86.95(\$ 39.47)$ \\
\hline $\begin{array}{r}\text { Average medical } \\
\text { encounter cost }\end{array}$ & $\begin{array}{l}\text { Total calendar year medical } \\
\text { care services costs } \div \text { total } \\
\text { medical care services encounters }\end{array}$ & $\$ 53.18(\$ 28.10)$ \\
\hline
\end{tabular}


Table 1. (Continued)

\begin{tabular}{|c|c|c|}
\hline Variable name & Definition & $\begin{array}{c}\text { Mean (stnd dev.) } \\
\text { Number (percentage) }\end{array}$ \\
\hline $\begin{array}{l}\text { Average enabling } \\
\text { services cost }\end{array}$ & $\begin{array}{l}\text { Total calendar year enabling and other } \\
\text { Medicare nonreimbursable services } \\
\text { costs } \div \text { total enabling services } \\
\text { encounters }\end{array}$ & $\$ 157.50(\$ 328.92)$ \\
\hline $\begin{array}{l}\text { Average personnel } \\
\text { cost }\end{array}$ & Total employee costs $\div$ total employees & $\$ 60,578.1(\$ 39,712.5)$ \\
\hline $\begin{array}{l}\text { Average medical } \\
\text { cost }\end{array}$ & $\begin{array}{l}\text { Total medical care services costs } \div \text { total } \\
\text { medical care services personnel }\end{array}$ & $\$ 73,988.1(\$ 40,171.1)$ \\
\hline $\begin{array}{l}\text { Average administrative } \\
\text { cost }\end{array}$ & $\begin{array}{l}\text { Total administration costs } \div \\
\text { administration staff }\end{array}$ & $\$ 100,584.3(\$ 209,794.0)$ \\
\hline \multicolumn{3}{|l|}{ Enabling services } \\
\hline Case management & $\begin{array}{l}\text { Number and percentage of centers that } \\
\text { provided this service }\end{array}$ & $597(97.2 \%)$ \\
\hline Child care & $\begin{array}{l}\text { Number and percentage of centers } \\
\text { that provided this service during } \\
\text { visit to center }\end{array}$ & $128(18.7 \%)$ \\
\hline Discharge planning & $\begin{array}{l}\text { Number and percentage of centers that } \\
\text { provided this service }\end{array}$ & $306(44.4 \%)$ \\
\hline Eligibility assistance & $\begin{array}{l}\text { Number and percentage of centers that } \\
\text { provided this service }\end{array}$ & $546(79.7 \%)$ \\
\hline $\begin{array}{l}\text { Employment/educational } \\
\text { counseling }\end{array}$ & $\begin{array}{l}\text { Number and percentage of centers that } \\
\text { provided this service }\end{array}$ & $145(21.2 \%)$ \\
\hline $\begin{array}{l}\text { Environmental health } \\
\text { risk reduction }\end{array}$ & $\begin{array}{l}\text { Number and percentage of centers } \\
\text { that provided this service (via } \\
\text { detection and/or alleviation) }\end{array}$ & $205(29.9 \%)$ \\
\hline $\begin{array}{l}\text { Food bank/delivered } \\
\text { meals }\end{array}$ & $\begin{array}{l}\text { Number and percentage of centers that } \\
\text { provided this service }\end{array}$ & $63(9.2 \%)$ \\
\hline Health education & $\begin{array}{l}\text { Number and percentage of centers that } \\
\text { provided this service }\end{array}$ & $658(96.1 \%)$ \\
\hline Housing assistance & $\begin{array}{l}\text { Number and percentage of centers that } \\
\text { provided this service }\end{array}$ & $154(22.5 \%)$ \\
\hline $\begin{array}{l}\text { Interpretation/translation } \\
\text { services }\end{array}$ & $\begin{array}{l}\text { Number and percentage of centers that } \\
\text { provided this service }\end{array}$ & $489(71.4 \%)$ \\
\hline $\begin{array}{l}\text { Nursing home and } \\
\text { assisted-living } \\
\text { placement }\end{array}$ & $\begin{array}{l}\text { Number and percentage of centers that } \\
\text { provided this service }\end{array}$ & $198(28.9 \%)$ \\
\hline Outreach & $\begin{array}{l}\text { Number and percentage of centers that } \\
\text { provided this service }\end{array}$ & $568(82.9 \%)$ \\
\hline
\end{tabular}

